ACTA UNIVERSITATIS NICOLAI COPER NICI DOI: http://dx.doi.org/10.12775/AUNC_ECON.2017.002 EKONOMIA $48 \mathrm{nr} 1$ (2017) 19-37

Pierwsza wersja złożona 12 sierpnia 2017

e-ISSN: 2392-1269

Końcowa wersja zaakceptowana 6 grudnia 2017

p-ISSN: 2080-0339

\author{
Tomasz Skica, Ruslan Harasym*
}

\title{
CZYNNIKI DETERMINUJACEE POZIOM AKTYWNOŚCI GOSPODARCZEJ NA PRZYKŁADZIE GMIN O NAJWYŻSZYM POZIOMIE PRZEDSIĘBIORCZOŚCI**
}

Z a rys treści. Niniejszy artykuł podejmuje próbę zbudowania profilu polskich gmin z uwzględnieniem czynników decydujących o wyższym (w relacji do pozostałych gmin) poziomie przedsiębiorczości. Dla realizacji tego celu, autorzy wzięli pod uwagę instrumenty wspierania przedsiębiorczości wykorzystywane przed samorządy gminne, jak również rozwiązania wykorzystywane przez instytucje otoczenia biznesu. Na podstawie analizy przestrzennej (globalnej i lokalnej statystyki I Morana) przedstawiano geograficzne rozmieszczenie klastrów gmin skupiających samorządy w obrębie, których identyfikowana jest podobna aktywność gospodarcza. Wykonane badanie zostało uzupełnione analizą czynników determinujących aktywność gospodarczą w gminach o najwyższym poziomie przedsiębiorczości. Badania wykazały, że przedsiębiorczość zależy nie tylko od instrumentów należących do jednostek samorządu terytorialnego. Wyższy poziom przedsiębiorczości jest silnie związany $\mathrm{z}$ innymi czynnikami. Jednym $\mathrm{z}$ nich jest wsparcie instytucjonalne udzielane przez lokalne instytucje pozarządowe. Kolejny czynnik jest związany z lokalizacją i korzyściami aglomeracyjnymi. Ostatni z nich jest sumą wszystkich czynników wymienionych powyżej. Oznacza to, że skupienie się wyłącznie na instrumentach wsparcia przedsiębiorczości przez jednostki sa-

\footnotetext{
*Adres do korespondencji: Tomasz Skica, Katedra Finansów, Wyższa Szkoła Informatyki i Zarządzania WSIiZ z siedzibą w Rzeszowie, Instytut Badań i Analiz Finansowych (IBAF) przy WSIiZ w Rzeszowie, ul. Sucharskiego 35-225 Rzeszów, e-mail: tskica@wsiz.rzeszow.pl; Ruslan Harasym, Katedra Ekonomii, Wyższa Szkoła Informatyki i Zarządzania WSIiZ z siedzibą w Rzeszowie, ul. Sucharskiego 35-225 Rzeszów, e-mail: rharasym@wsiz.rzeszow.pl.

** Artykuł został opracowany w wyniku realizacji projektu finansowanego ze środków Narodowego Centrum Nauki przyznanych na podstawie decyzji numer DEC2013/11/B/HS4/01022.

(C) 2017 Uniwersytet Mikołaja Kopernika. All rights reserved. http://www.aunc.ekonomia.umk.pl
} 
morządu terytorialnego nie wystarczy, aby skutecznie wspierać przedsiębiorców. Co najmniej równie ważne jak instrumenty, są inne czynniki, a wśród nich szczególnie ważną rolę pełni lokalizacja.

S łow a klu c z o we: aktywność gospodarcza, przedsiębiorczość, gminy o najwyższym poziomie przedsiębiorczości, instrumenty wspierania przedsiębiorczości, instytucje otoczenia biznesu (IOB), autokorelacja przestrzenna.

K 1 a s y fik a c j a J E L: L26, L31, L38.

\section{WSTĘP}

Zarówno $\mathrm{w}$ teorii jak i $\mathrm{w}$ praktyce gospodarczej podejmowanych jest wiele prób wyjaśniania zjawiska przedsiębiorczości z punktu widzenia czynników decydujących o jego poziomie. Co istotne licznym próbom i związanym z nimi podejściom metodologicznym towarzyszą częstokroć odmienne wyniki, co dodatkowo zwiększa dysonans poznawczy ${ }^{1}$. Interpretację czynników decydujących o poziomie przedsiębiorczości utrudnia także zróżnicowanie rezultatów osiąganych przez gminy stosujące te same formy wsparcia $^{2}$. Tym samym o ich skuteczności, bądź nieskuteczności - w działaniach na rzecz wspierania inicjatyw gospodarczych decydują także czynniki inne, aniżeli stosowane stymulatory. Kluczowym jest, więc pytanie o to w jakim stopniu przedsiębiorczość stanowi funkcję stosowanych przez władze lokalne instrumentów wsparcia przedsiębiorczości, a w jakim zakresie identyfikowany poziom aktywności ekonomicznej stanowi pochodną czynników niezwiązanych wprost z polityką samorządów gmin. Instrumenty wsparcia przedsiębiorczości dostępne jednostkom samorządu terytorialnego szczebla gminnego klasyfikowane są $\mathrm{w}$ bardzo różnorodny sposób (por. m.in. Bończak-Kucharczyk, Herbst i Chmura, 1998, s. 1-168; Słomińska, 2007, s. 19-33; Makieła, 2008, s. 18 i nast.; Kogut-Jaworska, 2008, s. 8788, Kożuch, 2011, s. 9-26; Gołębiowski i Korolewska, 2013, s. 9 i nast., Walania 2014, s. 61-73 i inne). Niezależnie jednak od przyjętej metody ich grupowania zwężają się one do trzech wymiarów. Pierwszy tworzą instru-

\footnotetext{
${ }^{1}$ Problematykę wspierania przedsiębiorczości z perspektywy stosowanych rozwiązań, a także uzyskiwanych przy ich zastosowaniu efektów prezentują T. Skica, T. Mickiewicz, J. Rodzinka, Lokalna polityka wsparcia przedsiębiorczości: Klasteryzacja, promocja, doradztwo $i$ kapitat spoteczny, Wydawnictwo C.H. Beck, Warszawa 2016, ISBN 978-83-255-8879-3 (C.H. Beck) oraz ISBN 978-83-64286-61-2 (WSIiZ), ss. 11-54,

${ }^{2}$ Szerzej na temat zróżnicowania efektów uzyskiwanych przez różne kategorie rodzajowe gmin przy zastosowaniu tych samych instrumentów wsparcia piszą m.in. T. Skica, E. InglotBrzęk, Zróżnicowanie efektów stosowania instrumentów wsparcia przedsiębiorczości przez samorzą terytorialny z uwagi na kryterium kategorii rodzajowej gminy, Samorząd Terytorialny, 2017, 6(318), ISSN 0867-4973, ss. 24-54.
} 
menty infrastrukturalne (w tym rozbudowa infrastruktury technicznej), drugi instrumenty prawno-organizacyjne, (wśród których wymienić należy ustalanie niższych niż maksymalnie dozwolonych stawek w podatkach lokalnych), a trzeci instrumenty promocyjne (obejmujące m.in. organizację działań zakładających promocję produktów lokalnych).

Mając na uwadze przedstawione wyżej stanowisko, autorzy niniejszego artykułu przyjęli za jego cel ustalenie cech indywidualizujących samorządy gminne $\mathrm{z}$ uwagi na poziom aktywności gospodarczej identyfikowany $\mathrm{w}$ obrębie ich granic administracyjnych. Celem niniejszego artykułu jest tym samym zbudowanie swego rodzaju profilu gmin z uwzględnieniem czynników decydujących o wyższym (w relacji do pozostałych gmin), poziomie przedsiębiorczości. Jak wykazano obok polityki władz lokalnych niewątpliwie kreującej warunki lokalizacji i prowadzenia działalności gospodarczej, źródeł sukcesu badanych gmin upatrywać należy także w innych czynnikach w tym w tzw. czynnikach aglomeracji (por. Polski, 2013, s. 142-149). Identyfikacja czynników sprawczych wyższej przedsiębiorczości przeprowadzona zostanie w kilku wzajemnie uzupełniających się wymiarach, przy wykorzystaniu szeregu metod i narzędzi badawczych. Przyjęte rozwiązanie zapewni miarodajność otrzymanych rezultatów tak w warstwie metodologicznej jak i w warstwie poznawczej.

\section{DANE I METODOLOGIA BADANIA}

Dobór próby badawczej zdeterminowany był założeniami realizowanego $\mathrm{w}$ czasie przygotowania artykułu projektu badawczego ${ }^{3}$ dofinansowanego przez Narodowe Centrum Nauki (NCN). W trakcie realizacji projektu korzystano z próby badawczej wylosowanej na potrzeby badania postaw i uwarunkowań przedsiębiorczości w Polsce prowadzonych w ramach międzynarodowego projektu badawczego Global Entrepreneurship Monitor (GEM). Dla zapewnienia kompatybilności zbieranych danych, a także możliwości ich dalszego zestawiania i analizowania, do badań dobrano tylko te gminy, które uczestniczyły w ostatniej edycji badań GEM w roku 2014 (było to 886 jednostek samorządu terytorialnego).

Badania ankietowe przeprowadzono przy wykorzystaniu metody CATI ( $\mathrm{z}$ ang. Computer Assisted Telephone Interviewing) i metody CAWI ( $\mathrm{z}$ ang. Computer Assisted Web Interviews) na próbie 886 gmin w okresie sierpieńpaździernik 2015 roku. Posłużyły one diagnozie zakresu stosowania przez

\footnotetext{
3 Projekt badawczy pt. „Wspieranie przedsiębiorczości przez samorząd terytorialny szczebla gminnego" realizowany na podstawie decyzji numer DEC-2013/11/B/HS4/01022
} 
badane jednostki samorządu terytorialnego szczebla gminnego dostępnych im instrumentów wsparcia przedsiębiorczości. W trakcie badań informacje zwrotne otrzymano od 731 gminy (tj. 82,5\% gmin poddanych badaniu) (por. Mapa 1).

Tabela 1. Dane wykorzystane w badaniu

\begin{tabular}{cccc}
\hline Nazwa & $\begin{array}{c}\text { Jednostki } \\
\text { terytorialne }\end{array}$ & $\begin{array}{c}\text { Wymiar } \\
\text { czasowy }\end{array}$ & Źródło danych \\
\hline Wyniki badań ankietowych & $731 \mathrm{gmin}$ & 2014 & $\begin{array}{l}\text { Własne badania ankietowe } \\
\text { przeprowadzone w ramach } \\
\text { projektu badawczego NCN }\end{array}$ \\
$\begin{array}{c}\text { Liczba nowo zarejestrowanych } \\
\text { podmiotów gospodarczych } \\
\text { Liczba ludności w wieku } \\
\text { produkcyjnym }\end{array}$ & $731 \mathrm{gmin}$ & 2014 & Bank Danych Lokalnych (GUS) \\
\hline
\end{tabular}

*Zebrane dane uzupełnione zostały o analizę stron www gmin o najwyższym poziomie przedsiębiorczości i działających na ich obszarze organizacji pozarządowych (w tym instytucji otoczenia biznesu (IOB)) zorientowanych na wspieranie rozwoju gospodarczego.

Źródło: Opracowanie własne.

Badanie miało charakter czteroetapowy. W ramach I-go etapu spośród gmin poddanych badaniom ankietowym, na podstawie najwyższych wartości wskaźnika przedsiębiorczości ${ }^{4}$, wytypowano 15 gmin (por. Mapa 2). W kolejnym kroku na podstawie wyników badań ankietowych ustalono listę instrumentów stosowanych przez władze tych gmin w procesie wspierania przedsiębiorczości.

Stworzenie całościowego obrazu strategii wspierania przedsiębiorczości przez poszczególne gminy wiązało się z koniecznością skoncentrowania się w II etapie badań na przeanalizowaniu źródeł wtórnych (artykułów naukowych i innych opracowań dostępnych w Internecie, jak również stron internetowych poszczególnych gmin), w celu wychwycenia dodatkowych - także unikatowych działań/instrumentów stosowanych przez władze lokalne, których ewentualnie nie udało się zidentyfikować za pośrednictwem przeprowadzonej ankietyzacji.

Poza działaniami władz lokalnych na poziom przedsiębiorczości w poszczególnych gminach mogą także oddziaływać organizacje pozarządowe, których bezpośrednim lub pośrednim celem jest wspieranie przedsiębiorczości. Dlatego też III etap badań poświęcono przeanalizowaniu wytypowanych gmin przez pryzmat funkcjonowania/niefunkcjonowania na ich terenie orga-

\footnotetext{
${ }^{4}$ Stosunek liczby nowo zarejestrowanych przedsiębiorstw w gminie do liczby ludności w wieku produkcyjnym w gminie. Wskaźnik obliczono na podstawie danych GUS.
} 
nizacji pozarządowych oraz wykorzystywanych przez funkcjonujące jednostki instrumentów/działań ukierunkowanych na wspieranie przedsiębiorczości.

Mapa 1. Terytorialny rozkład gmin, których pracownicy wypełnili ankietę

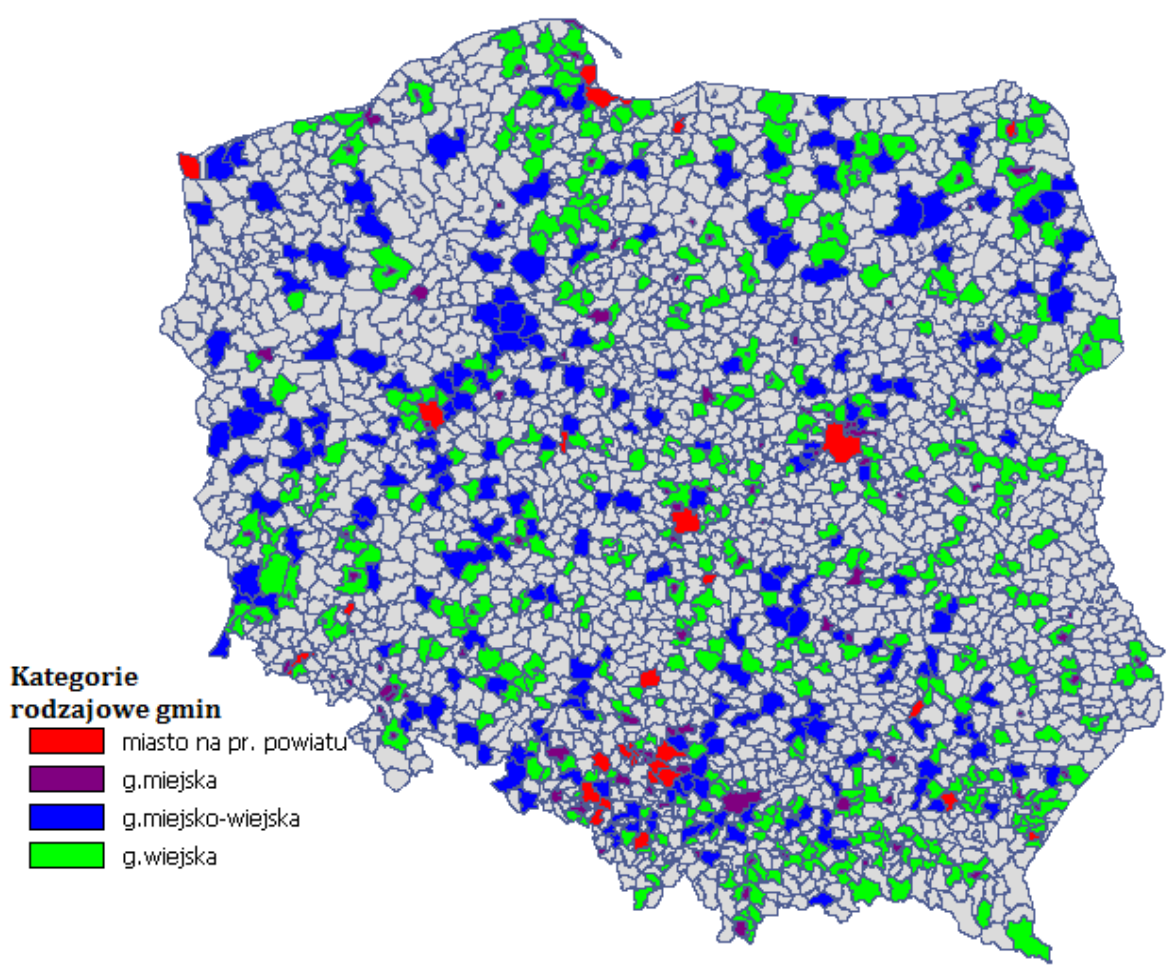

Źródło: opracowanie własne na podstawie danych GUS.

Wyższy poziom przedsiębiorczości w gminie poddanej analizie może być także wynikiem sąsiedztwa w pobliżu dużych aglomeracji, albo innych mniejszych gmin charakteryzujących się wyższym poziomem wskaźnika przedsiębiorczości. W celu zbadania powyższej tezy w IV etapie badań przeprowadzono analizę przestrzenną na podstawie statystyki globalnej I Morana ${ }^{5}$. W ramach analizy zbadano, czy wyższy wskaźnik przedsiębiorczości wśród polskich gmin zależy/nie zależy od lokalizacji geograficznej. Na

\footnotetext{
5 Analiza, która bada stopień intensywności danej cechy w obiektach przestrzennych. Wszystkich niezbędnych obliczeń dokonano za pomocą oprogramowania PQstat, (przyp. aut.).
} 
podstawie statystyki lokalnej I Morana ${ }^{6}$ oraz Getisa i Orda ${ }^{7}$ opracowano mapę klastrów gmin cechujących się podobnym poziomem wskaźnika przedsiębiorczości.

Mapa 2. Gminy wytypowane do szczegółowych analiz

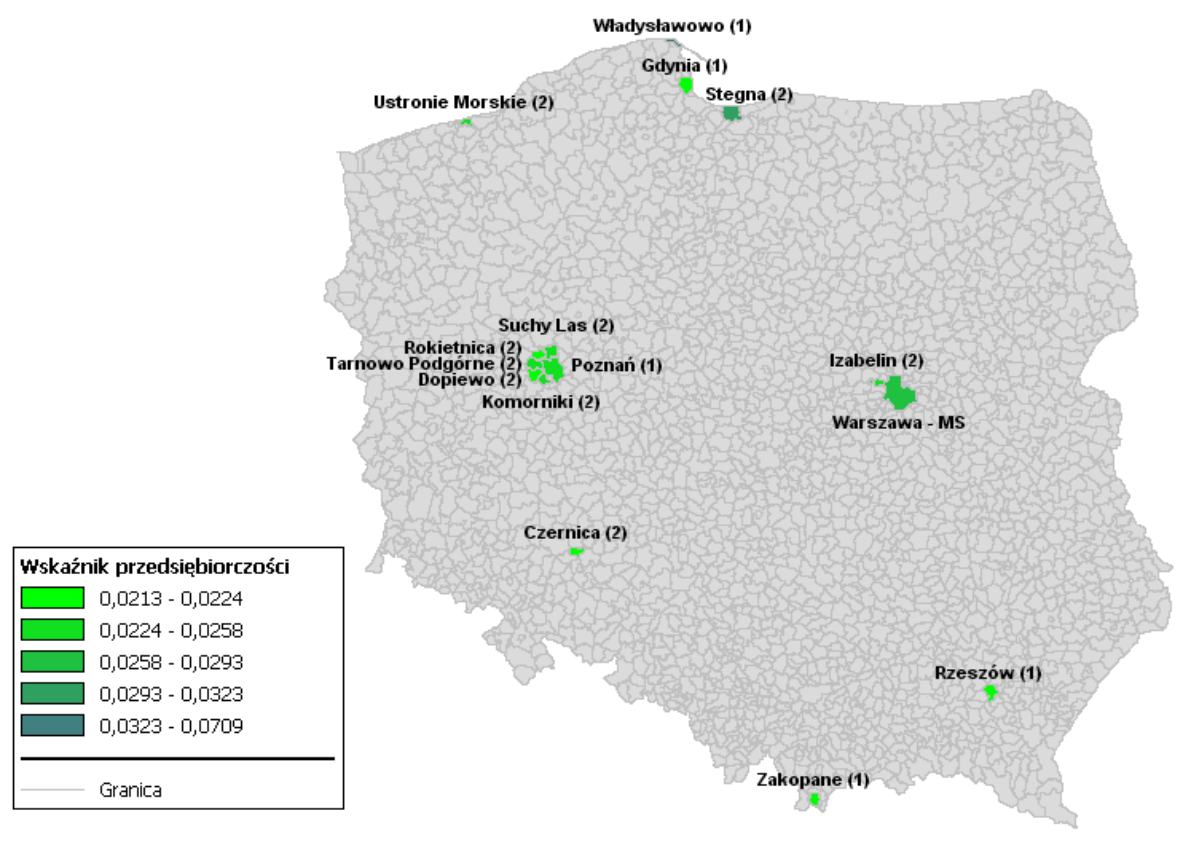

* Cyfra podana w nawiasie obok nazwy gminy oznacza typ gminy według nomenklatury GUS

Źródło: Opracowanie własne na podstawie danych GUS.

\footnotetext{
${ }^{6}$ Lokalna wersja statystyki Morana jest najbardziej popularną analizą określaną, jako LISA (Local Indicators of Spatial Association). W odróżnieniu od globalnej statystyki Morana wyznacza ona lokalną autokorelację przestrzenną, a zatem określa podobieństwo jednostki przestrzennej wobec sąsiadów i bada istotność statystyczną tej zależności. Wszystkich niezbędnych obliczeń dokonano za pomocą oprogramowania PQstat, (przyp. aut.).

${ }^{7}$ Statystyka lokalna $\mathrm{G}_{\mathrm{i}}$ Getisa i Orda umożliwia wykrywanie lokalnej koncentracji wartości wysokich i niskich w sąsiadujących obiektach oraz bada istotność statystyczną tej zależności. Getis i Ord zdefiniowali również bliźniaczą do $G_{i}$ statystykę $G_{i}^{*}$ która różni się od $G_{i}$ jedynie tym, że obiekt dla którego wykonuje się badanie również bierze udział w analizie. $\mathrm{W}$ macierzy wag jest, więc zdefiniowane dla niego sąsiedztwo z samym sobą tzw. potencjał (wartości na przekątnej są większe od 0). Wszystkich niezbędnych obliczeń dokonano za pomocą oprogramowania PQstat, (przyp. aut.).
} 


\section{ANALIZA EMPIRYCZNA I PREZENTACJA WYNIKÓW BADAŃ}

Zgodnie $\mathrm{z}$ nakreślonym powyżej schematem prac badawczych, pierwszym etapem badań była analiza instrumentów wspierania inicjatyw gospodarczych wykorzystywanych przez gminy o wyższym poziomie przedsiębiorczości. Na podstawie analizy materiału ankietowego zbudowano profil gmin, z uwagi na kryterium stosowanych przez nie instrumentów. W trakcie badań ustalono, że wszystkie gminy o wyższym poziomie przedsiębiorczości posiadały strategię rozwoju utworzoną przy współudziale lokalnych przedsiębiorców, dysponowały planem zagospodarowania przestrzennego, który obejmował min 50\% powierzchni gminy, (z której przynajmniej 10\% stanowiły tereny przeznaczone na działalność gospodarczą), a w obrębie ich granic administracyjnych uzbrojono nowe tereny inwestycyjne.

Pracownicy gmin w obrębie, których wskaźnik przedsiębiorczości był wyższy, informowali mieszkańców o możliwościach finansowania działalności gospodarczej (w tym m.in. z środków UE), wykorzystując do tego celu Internet oraz spotkania bezpośrednie. Pracownicy tych jednostek angażowali się również $\mathrm{w}$ prowadzenie szkoleń przygotowujących do podjęcia i prowadzenia działalności gospodarczej, a na terenie reprezentowanych przez nich gmin funkcjonowały stowarzyszenia lub fundacje (w tym także instytucje otoczenia biznesu - IOB), wspierające przedsiębiorców.

$\mathrm{W}$ gminach o wyższym poziomie przedsiębiorczości swoją działalność lokalizowały punkty obsługi firm oferujące porady prawne oraz finansowoksięgowe, a przynajmniej część usług komunalnych w gminie świadczona była przez firmy prywatne. W gminach skutecznie wspierających przedsiębiorczość wprowadzono preferencyjne stawki w podatku od środków transportowych i w podatku od nieruchomości, a także ulgi dla nowopowstających firm. Gminy prowadziły równolegle działania na rzecz pozyskania inwestorów wykorzystując do tego celu działania marketingowe, reklamę gminy w wymiarze ponadlokalnym, rozpowszechnianie materiałów o gminie (w kilku językach), promowanie jej oferty na targach zagranicznych, a także oferując firmom pomoc $\mathrm{w}$ znalezieniu wolnych gruntów i/lub lokali oraz wsparcie na etapie rejestracji działalności.

Finalnie, w gminach o wyższym poziomie przedsiębiorczości władze lokalne brały udział w spotkaniach z mieszkańcami, kontaktowały się z nimi w sposób interaktywny (np. poprzez fora internetowe), a mieszkańcy częściej niż w pozostałych gminach uczestniczyli w sesjach ich organów. Gminy o wyższej przedsiębiorczości prowadziły badania ilościowe i jakościowe dotyczące uwarunkowań rozwoju społeczno-ekonomicznego angażując w nie mieszkańców, a ponadto realizowały szeroką politykę informacyjną 
w obszarze przedsiębiorczości m.in. z wykorzystaniem portali informatycznych (w tym stron www urzędu).

Drugim etapem prac badawczych była analiza zawartości serwisów i stron internetowych. Badaniu poddano strony www urzędów gmin, BIP, a także strony internetowe portali tematycznych w kierunku zidentyfikowania unikatowych rozwiązań stosowanych przez badane JST w działaniach służących wsparciu firm. Przeprowadzone badania pozwoliły na sformułowanie dwóch wniosków. Po pierwsze, analizy nie wykazały stosowania przez JST o wyższym poziomie przedsiębiorczości unikatowych rozwiązań, które mogłyby stanowić czynnik przewagi w rywalizacji o nowe firmy. Po drugie, badania dowiodły, że poddane ocenie gminy nie prowadzą przejrzystej, konsekwentnej, a przy tym kompleksowej polityki informacyjnej na temat form wsparcia, z których korzystać mogą podmioty potencjalnie zainteresowane rozpoczęciem działalności na terenie gminy. Przedsiębiorcy dowiadują się o nich dopiero w bezpośrednich kontaktach $\mathrm{z}$ urzędem. Wysoce prawdopodobne jest więc także to, że o części z nich nie wiedzą pomimo zlokalizowania na danym terenie działalności gospodarczej.

Zaprezentowane ustalenia pozwalają stwierdzić, że o lokalizacji działalności decydują także (a niekiedy przede wszystkim), inne czynniki, aniżeli instrumentarium wsparcia przygotowane w tym celu przez gminę. Spostrzeżenie to potwierdza postawioną we wstępnie artykułu hipotezę badawczą zgodnie, z którą czynniki lokalizacyjne wykraczają poza sferę instrumentów wsparcia stosowanych wobec firm przez jednostki samorządu terytorialnego. Rozwinięcie tego wątku stanowi analiza struktury próby badawczej. Gminy o najwyższym poziomie przedsiębiorczości to przede wszystkim gminy wiejskie, zlokalizowane w pobliżu dużych ośrodków miejskich. Są to gminy czerpiące korzyści lokalizacyjne (z uwagi na niewielki dystans do gmin pełniących rolę centrów wzrostu w regionie), o dużym potencjale rozwojowym (m.in. za sprawą przewidywalności wpływów budżetowych), cechujące się niższymi kosztami prowadzenia działalności (m.in. z uwagi na niższe koszty pracy), a przy tym często dysponujące powierzchnią pod działalność gospodarczą nieograniczoną tak restrykcyjnie zapisami planów zagospodarowania przestrzennego jak ma to miejsce w przypadku gmin miejskich.

Potwierdzeniem spostrzeżeń dotyczących gmin o wyższej przedsiębiorczości, upatrujących innych niż instrumenty JST czynników decydujących o lokalizacji działalności gospodarczej jest to, iż niemal połowa spośród nich (tj. $6 \mathrm{z} 15$-stu badanych jednostek), nie umieszcza na stronach www informacji o rozwiązaniach, za pośrednictwem których wspiera przedsiębiorczość. Nie informuje tym samym o możliwych oferowanych formach wsparcia dla firm. Nieco lepiej na tle grupy gmin o wyższym poziomie 
przedsiębiorczości wypadają miasta na prawach powiatu, znaczenie słabiej natomiast gminy wiejskie. $\mathrm{O}$ ile te pierwsze za pośrednictwem stron www deklarują wsparcie oferowane przedsiębiorcom (w szczególności na etapie zakładania działalności), o tyle gminy wiejskie w przeważającej mierze nie prowadzą polityki informacyjnej nawet $\mathrm{w}$ tak ograniczonym zakresie jak czynią to miasta na prawach powiatu.

Zaobserwowana praktyka polegająca na braku pełnej, powszechnie dostępnej i aktualizowanej informacji o możliwych do skonsumowania przez przedsiębiorców formach wsparcia (oferowanego przez JST), przekłada się na brak zainteresowania nimi ze strony podmiotów gospodarczych. Sytuacja ta jest obustronnie niekorzystna. Z punktu widzenia JST oznacza ona działania służące tworzeniu rozwiązań nieupowszechnianych, a przez to nieimplementowanych w pełnym zakresie do praktyki gospodarczej. Skala skuteczności opracowanych przez JST instrumentów wsparcia jest tym samym znacznie mniejsza od potencjalnej. Nie przekłada się ona w pełni na realizację zamierzonych efektów (tj. skali i zakresu symulowania aktywności gospodarczej w gminie). Opisane rozwiązanie pozostaje także ze stratą dla samych przedsiębiorców, którzy w sytuacji zbliżonych uwarunkowań lokalnych szukają argumentów na rzecz lokalizacji działalności na danym terenie. Brak informacji o rozwiązaniach wspierających przedsiębiorczość zaprzepaszcza wtórnie potencjalne szanse JST na zlokalizowanie działalności gospodarczej w gminie gdyż ukierunkowuje szukanie argumentów przemawiających za lokalizacją poza wsparcie oferowane z poziomu JST.

Trzecim etapem analiz była działalność organizacji pozarządowych ukierunkowanych na tworzenie warunków dla rozwoju społeczno - ekonomicznego wspólnot lokalnych. Gminy o wyższym poziomie wskaźnika przedsiębiorczości wspierały obok przedsiębiorców także organizacje pozarządowe aczkolwiek wsparcie to nie miało charakteru finansowego, lecz przyjmowało formę udostępniania lokali na działalność statutową, a także udostępniania niezbędnych do tego celu materiałów i sprzętów. Gminy informowały o dostępnych środkach pozabudżetowych dla ww. podmiotów, a także promowały organizacje pozarządowe działające $\mathrm{w}$ obszarze pożytku publicznego. W strukturze urzędu wyznaczana była osoba koordynująca współpracę z organizacjami pozarządowymi, tworzone były zespoły, których członkami byli pracownicy gminy i członkowie IOB. Efektem tak zorganizowanej kooperacji była współpraca w sferze programowej, a także w sferze planowania oraz realizacji wspólnych przedsięwzięć, w tym projektowania budżetu w zakresie dotyczącym działania organizacji pozarządowych.

Uzupełnieniem powyższych ustaleń dotyczących współpracy gmin z instytucjami otoczenia biznesu opisywanych z perspektywy urzędu, było ba- 
danie aktywności IOB ukierunkowanej na przedsiębiorczość. W tym celu z grupy 15 badanych JST usunięto 5 dużych miast na prawach powiatu i jedną gminę miejską, a do dalszego badania pozostawiono 9 gmin wiejskich i 1 gminę miejsko-wiejską. Zabieg ten umożliwił wyeliminowanie problemu zaburzania interpretacji wyników przez jednostki zlokalizowane na terenie dużych ośrodków miejskich z natury odznaczających się wyższym poziomem przedsiębiorczości (Russel, Grycyk, 2014, s. 65-83). Do wytypowanych $\mathrm{w}$ ten sposób gmin przyporządkowano organizacje, których zakres działalności nawiązywał (przynajmniej pośrednio) do rozwoju społecznoekonomicznego. Następnie spośród zarejestrowanych organizacji wytypowano te, które dysponowały programami współpracy z JST, na których były zlokalizowane. Analizie poddano treść programów wytypowanych organizacji celem ustalenia, czy znajdują się w nich działania służące wsparciu rozwoju gospodarczego. Spośród zbadanych programów tylko 3 gminy i 9 działających na ich terenie IOB umieściły w planach swojej działalności - aktywności na rzecz stymulowania rozwoju gospodarczego.

Analiza treści programów organizacji pozarządowych (IOB) nie wykazała unikatowych działań na rzecz stymulowania przedsiębiorczości (Matejun 2005, 49-60). Podmioty te deklarują działania służące rozwojowi gospodarczemu i wsparciu dla firm, ale nie informują o instrumentach, ani rozwiązaniach, które mają służyć realizacji tak zapisanych celów. Dysponując informacjami o roli instytucji otoczenia biznesu $\mathrm{w}$ procesie wspierania przedsiębiorczości opisywanej tak z perspektywy samych IOB jak i samorządów, w których zostały zlokalizowane zbudowano (podobnie jak w przypadku gmin), profil IOB ukierunkowanej na rozwój gospodarczy. Badanie dowiodło, że IOB ukierunkowane w swej działalności na wsparcie rozwoju gospodarczego (podobnie jak JST), nie informują za pośrednictwem stron www o instrumentach ukierunkowanych na pomoc dla firm, które posiadają w swoim portfolio. Programy współpracy organizacji pozarządowych z gminami zawierają ogólnie nakreślone cele (takie jak „wspólne inicjatywy na rzecz rozwoju gospodarczego"), a przy tym nie odwołują się do katalogu działań podejmowanych $\mathrm{w}$ związku ze wsparciem przedsiębiorczości. W rezultacie tylko 2 spośród 9 badanych organizacji zawarły w swojej ofercie inicjatywy ukierunkowane wprost na wsparcie przedsiębiorczości i umieściły informację na ten temat zarówno na stronie www jak i w treści programu współpracy z JST. Przy czym nawet w tym przypadku są to działania realizowane standardowo obejmujące doradztwo biznesowe i promowanie (wspomaganie), prywatnej przedsiębiorczości zwłaszcza na etapie organizowania i rozwoju. Tylko 1-na, badana IOB, wskazała nieco szerszy katalog działań wspierających przedsiębiorczość uwzględniający obok ww. działań 
również pomoc firmom w stosowaniu nowych rozwiązań w organizacji i zarządzaniu, pomoc firmom prowadzącym badania i wdrążającym nowe technologie oraz nowe rozwiązania, kształcenie, reorientację zawodową i pomoc w pozyskiwaniu wykwalifikowanych kadr, propagowanie możliwości współpracy MSP z Polski z podmiotami spoza kraju (ze szczególnym uwzględnieniem krajów UE), a finalnie pomoc w pozyskiwaniu inwestorów krajowych i zagranicznych.

Czwartym etapem prac badawczych była analiza przestrzenna przeprowadzona dla wszystkich polskich gmin na podstawie statystyki globalnej I Morana $(I=0.462728)$ wskazała ona na istnienie dodatniej autokorelacji przestrzennej pod względem wskaźnika przedsiębiorczości wśród polskich gmin. Gminy bliskie siebie geograficznie tworzą klastry gmin cechujące się podobnym poziomem przedsiębiorczości (por. Mapa 3 oraz Aneks Tabela 1 i Wykres 1).

Mapa 3. Zróżnicowane poziomu przedsiębiorczości w przekroju jednostek samorządu terytorialnego szczebla gminnego

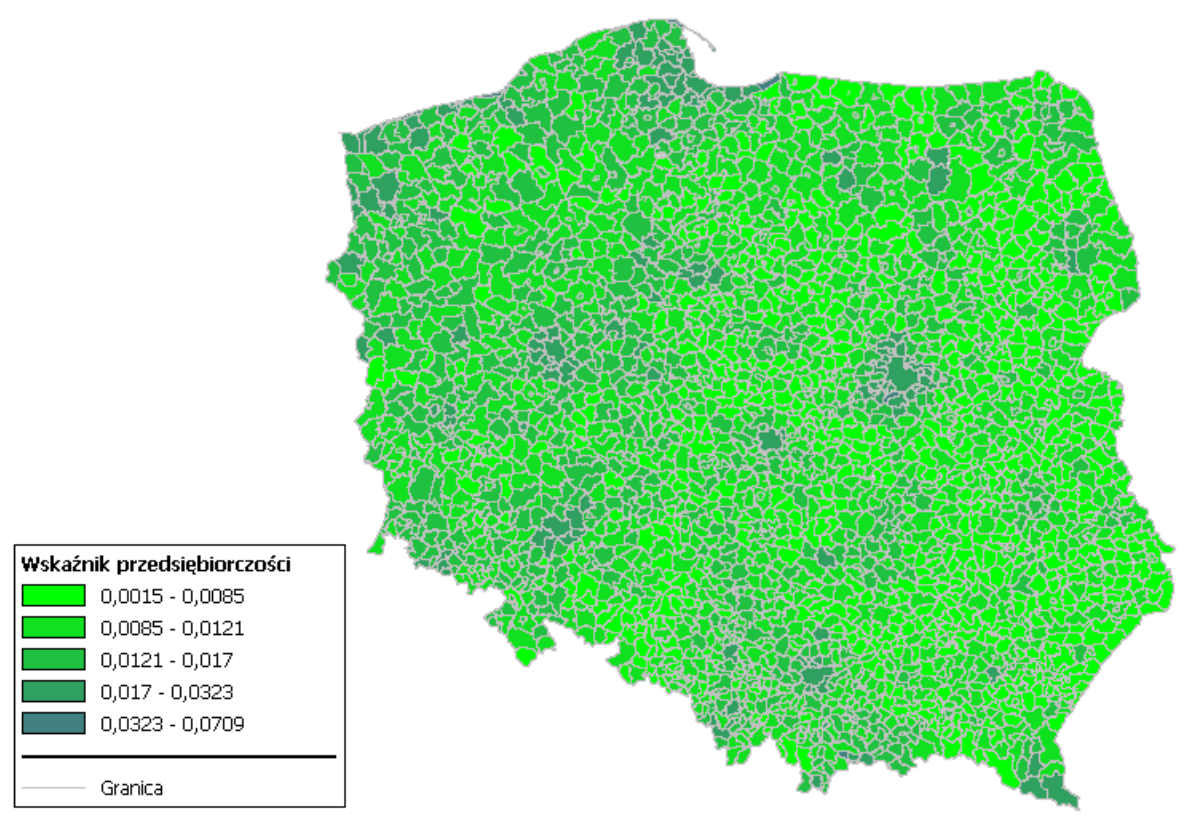

Źródło: opracowanie własne na podstawie danych GUS. 
Gminy charakteryzujące się wyższym wskaźnikiem przedsiębiorczości znajdują się w bliskim sąsiedztwie gmin o wysokim poziomie przedsiębiorczości. Klastry wysokiej przedsiębiorczości tworzą się wokół dużych miast, albo na obszarach, które charakteryzują się historycznie zakorzenionymi i rozwiniętymi specyficznymi specjalizacjami (np. Rzeszów), lub znajdujących się w pobliżu zachodnich granic Polski (np. Poznań).

W tym miejscu trzeba także zaznaczyć, że dodatnia autokorelacja przestrzenna występuje również w przypadku gmin o niskim poziomie przedsiębiorczości. Gminy oddalone geograficznie od gmin przodujących pod względem wskaźnika przedsiębiorczości tworzą klastry gmin o niskim poziomie przedsiębiorczości. W trakcie dalszych analiz, na podstawie statystyki lokalnej $I$ Morana (odpowiednio z niewygładzoną i wygładzoną zmienną o nazwie wskaźnik przedsiębiorczości) oraz Gi Getisa i Orda zidentyfikowano klastry gmin o wysokim i niskim poziomie przedsiębiorczości (por. Mapa 4 oraz Aneks Tabela 2 i 3 ).

Mapa 4. Mapa klastrów gmin ze względu na poziom przedsiębiorczości

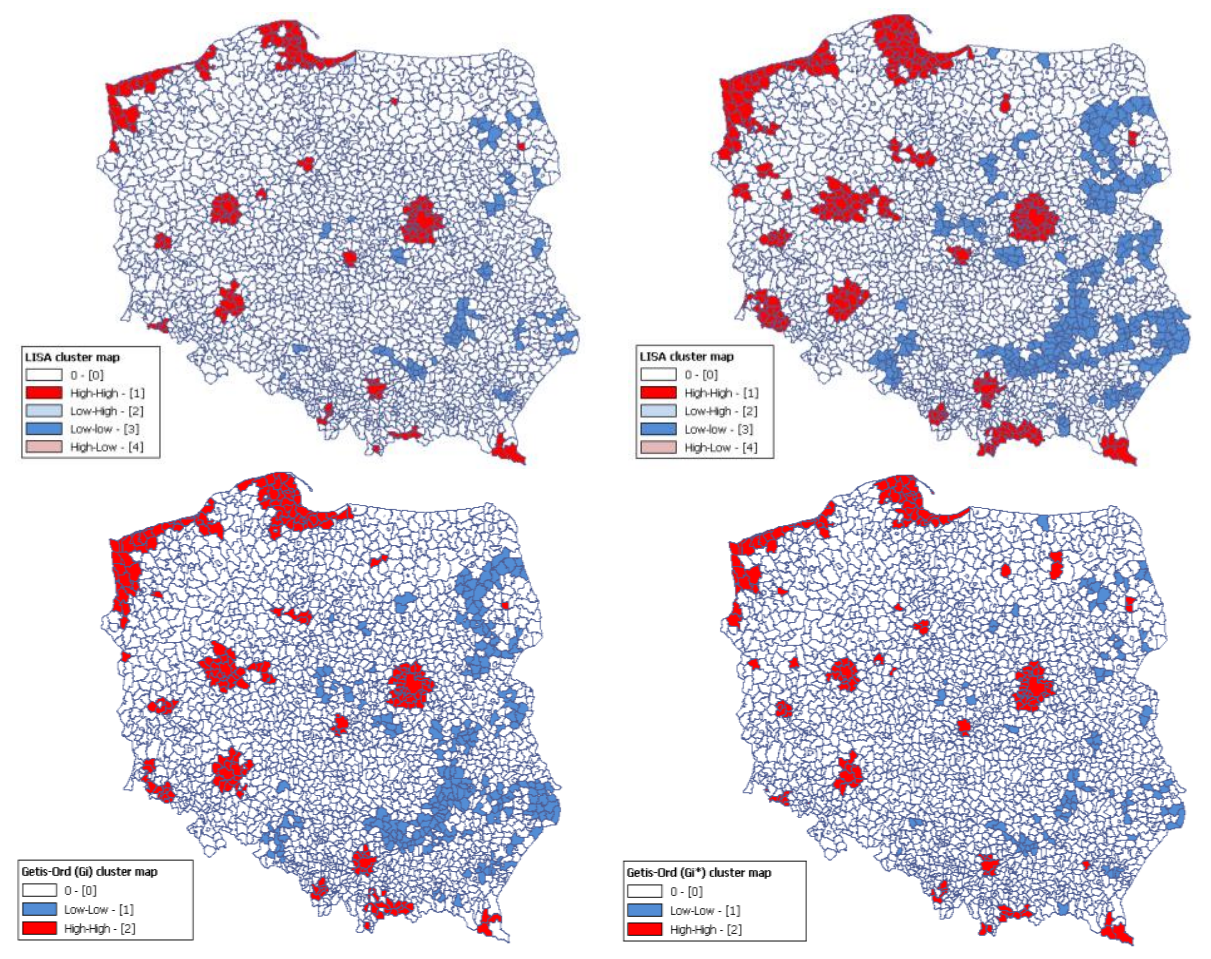


Źródło: Opracowanie własne na podstawie danych GUS oraz macierzy sąsiedztwa wygenerowanej w oprogramowaniu PQStat.

\section{PODSUMOWANIE}

Przeprowadzona analiza dowiodła kilku istotnych faktów, spośród których najważniejszym wydaje się ten, iż skuteczność rozwiązań na rzecz wspierania przedsiębiorczości jest wypadkową kilku stosowanych rozwiązań, a nie efektem implementacji tylko jednego instrumentu. Owo spostrzeżenie pozwala wysunąc kolejny wniosek zgodnie, z którym o zaklasyfikowaniu instrumentu do grupy skutecznych, czy też nieskutecznych form wsparcia decyduje często (a być może przede wszystkim), jego zestawienie $\mathrm{z}$ innymi stosowanymi instrumentami. Efekt stosowania pojedynczego instrumentu obniżany jest więc nie tylko przez jego bardziej lub mniej celowy dobór, lecz również przez koncentrację polityki wsparcia gminy wyłącznie na jednym rozwiązaniu, a przez to przeszacowanie skuteczności zastosowanej formy wsparcia. Pogląd ten koresponduje ze stanowiskiem wyrażanym m.in. przez takich autorów jak: (Skica, 2009, s. 240), (Kraśnicka, 2002, s. 240-245), a także (Matejun, 2012, s. 82-109) oraz (Dyrda, 2014, s. 89-99).

W zakresie uzyskanych wyników okazało się także, iż potencjalną skuteczność działań na rzecz wsparcia przedsiębiorczości obniżała relatywnie słaba polityka informacyjna samorządów, a niekiedy wręcz jej brak. Problem ten uwidocznił się również w trakcie badań nad IOB, które podobnie jak samorządy „nie doceniały” znaczenia polityki informacyjnej w obszarze dostępnego wsparcia inicjatyw gospodarczych. Tymczasem niepełna informacja, a niekiedy wprost jej brak był podstawowym czynnikiem decydującym o niższej wiedzy na temat obecnych na danym terenie form wsparcia, a tym samym ich niewielkim konsumowaniu przez adresatów działań stymulacyjnych (Kamińska 2012, 53-65; Dziemianowicze i inni, 2000, s. 9). Mając na uwadze powyższe należy powołać się na badania T. Dorożyńskiego, które dowodzą, że czynnikiem sprawczym kontaktów przedsiębiorców z IOB nie jest oferowane przez instytucje wsparcie, lecz niemożność skorzystania z niektórych programów pomocowych dla firm bez udziału IOB (Dorożyński, 2013, s. 135-150). Fakt ten odwraca naturalny porządek. IOB przestają być wiodącym źródłem wsparcia i w niektórych przypadkach stają się one jedynie koniecznym do przejścia etapem na drodze do jego otrzymania ze źródeł zlokalizowanych poza sferą aktywności IOB.

Istotnym z punktu widzenia tematyki artykułu okazały się być także rezultaty badań nad IOB. Wykonane badania dowiodły, że za wyższą przed- 
siębiorczością na danym terenie nie stoją żadne unikatowe i niespotykane w działalności innych IOB formy aktywności wspierające tworzenie firm (co potwierdza spostrzeżenia poczynione $\mathrm{w}$ stosunku do polityki JST wobec przedsiębiorczości). Dla zweryfikowania poprawności tego stwierdzenia badania wykonane na próbie IOB zlokalizowanych w gminach o wyższym poziomie przedsiębiorczości odniesiono do działalności instytucji otoczenia biznesu wspierających aktywność gospodarczą na terenie wybranych losowo gmin zlokalizowanych na terenie całego kraju. Badania wykonano z wykorzystaniem CATI oraz uzupełnieniem w postaci badań focusowych i kwestionariuszowych. Analizie poddano wybrane losowo IOB, które zgodziły się na udział $\mathrm{w}$ badaniu. ${ }^{8}$. Ich wynik potwierdził poczynione ustalenia badawcze. Badane instytucje angażują się w działania wspierające lokalny rozwój gospodarczy (z niewielkimi wyjątkami), w sposób analogiczny jak czynią to IOB funkcjonujące $\mathrm{w}$ gminach o wyższej przedsiębiorczości. Pośrednio stanowisko to potwierdzają (Szepelska, 2015, s. 367-378), (Gęca, 2012, s. 233-243), a także (Wychowanek, 2014, s. 151) oraz (Płoszaj, 2015) wskazując na profile działań służących wsparciu aktywności gospodarczej oferowane przez IOB w Polsce.

Zebrane informacje pozwalają sądzić, że o wyższej przedsiębiorczości na danym terenie nie decyduje wyższa skuteczność wsparcia udzielanego przez IOB, czy też samorząd terytorialny. Nie decydują o niej także odmienne rozwiązania oferowane przez IOB w sferze wsparcia dla przedsiębiorczości. Tym samym działania działalność IOB uznać należy za ważną i konieczną, ale jednocześnie niewystarczającą dla oczekiwanej ponadprzeciętnej skuteczności wsparcia dla przedsiębiorczości. Dla skuteczności inicjatyw podejmowanych przez samorządy i towarzyszące im otoczenie instytucjonalne niezmiernie ważny okazuje się być więc odpowiedni sposób kompilowania ze sobą stosowanych form wsparcia, a nade wszystko adresat tych działań opisywany przez poziom kapitału społecznego danego obszaru i uzupełniany o tradycje przedsiębiorczości, przewagi lokalizacyjne oraz historię aktywności gospodarczej na danym terenie (Saar, 2011). Zdaniem autorów są to determinanty, które obok aktywności JST oraz wsparcia IOB dopełniają kata$\log$ uwarunkowań rozwojowych przedsiębiorczości na danym terenie. Zagadnienia te stanowią jednakże przedmiot rozważań autorów poczynionych w treści odrębnych artykułów naukowych (Skica, Rodzinka, Harasym

\footnotetext{
${ }^{8}$ Badanie wykonano w roku 2016 na próbie piętnastu instytucji otoczenia biznesu (IOB). Instytucje dobrano według schematu losowania bez zwracania, wykorzystując do tego celu dane adresowe i profile ich działalności zamieszczone w bazie www.klon.org.pl (przyp. aut.).
} 
2016a, s. 164-165; Skica, Rodzinka, Harasym, 2016b, s. 257-269; Skica, Inglot-Brzęk, 2017, s. 24-54; Skica, Inglot-Brzęk, 2017a, s. 57-82).

Przeprowadzona analiza przestrzenna wskazuje na istnienie dodatniej autokorelacji pod względem wskaźnika przedsiębiorczości wśród polskich gmin. Gminy charakteryzujące się wyższą przedsiębiorczością (duże miasta/aglomeracje takie jak Warszawa, Kraków, Poznań jak również gminy sąsiadujące z Niemcami), tworzą klastry gmin o wysokiej przedsiębiorczości (kombinacje Wysoka-Wysoka). Zaprezentowane spostrzeżenie nawiązuje do powołanych we wstępie korzyści aglomeracji, które z uwagi na uzyskane wyniki prac badawczych zdają się najlepiej wyjaśniać czynniki sprawcze wyższej przedsiębiorczości w obrębie badanych gmin. W tym samym czasie gminy odstające pod względem wskaźnika przedsiębiorczości tworzą wokół siebie klastry gmin charakteryzujących się niższą przedsiębiorczością (kombinacje Niska-Niska). Otrzymane wyniki niosą ze sobą pozytywne interpretacje. Mianowicie w przekroju polskich gmin (w ramach przedstawionych klastrów gmin), widzimy efekt „rozlewania się” przedsiębiorczości do gmin sąsiadujących z dużymi aglomeracjami, z drugiej zaś strony mapy klastrów gmin wskazują na istnienie dysproporcji pod względem poziomu przedsiębiorczości między Wschodnią i Zachodnią Polską. Większość klastrów wysokiej przedsiębiorczości zlokalizowanych jest w zachodniej, bardziej rozwiniętej części kraju. We wschodniej części kraju dominują zaś klastry niskiej przedsiębiorczości. Dalsze utrzymywanie się powyższej tendencji na pewno nie będzie sprzyjać wyrównywaniu się poziomu rozwoju gospodarczego polskich regionów. Efektywność strategii wspierania przedsiębiorczości na poziomie lokalnym niewątpliwie w dużym stopniu zależy od jej kompatybilności ze strategią rozwoju regionalnego, która za swój główny cel stawić powinna wspomaganie/promowanie tych obszarów aktywności gospodarczej, które pozwolą zbudować przewagę konkurencyjną poszczególnych regionów.

\section{LITERATURA}

Bończak-Kucharczyk E., Herbst K., Chmura K. (1998), Jak władze lokalne moga wspierać przedsiębiorczość, Fundacja Inicjatyw Społeczno-Ekonomicznych, Fundacja Promocji Małych i Średnich Przedsiębiorstw, Warszawa.

Dorożyński T. (2013), Instytucje otoczenia biznesu a rozwój przedsiębiorstw - ujęcie regionalne, „Zarządzanie i Finanse”, 11(1), 135-150.

Dyrda G. (2014), Działania samorządu terytorialnego wspierające przedsiębiorczość - determinantę rozwoju lokalnego, wspierania lokalnej przedsiębiorczości (na przykładzie wybranych gmin Podkarpacia), „Gospodarka i Finanse”, Staropolska Szkoła Wyższa w Kielcach, 4, 89-99. 
Dziemianowicz W., Mackiewicz M., Malinowska E., Misiąg W., Tomalak M. (2000), Wspieranie przedsiębiorczości przez samorząd terytorialny. Raport Instytutu Badań nad Gospodarką Rynkową, Wydawnictwo PAB-Font, Warszawa.

Gęca B. (2012), Analiza form wsparcia instytucji otoczenia biznesu dla sektora MŚP na przykładzie województwa lubelskiego, „Journal of Management and Finance”, 10, 233243.

Gołębiowski G., Korolewska M. (2013), Wspieranie rozwoju przedsiębiorczości przez jednostki samorzadu terytorialnego w Polsce. Raport z badań, Wydawnictwo Sejmowe, Warszawa.

Kamińska A. (2012), Wplyw instytucji otoczenia biznesu na rozwój matych i średnich przedsiębiorstw w regionie lubelskim, „Barometr Regionalny”, 1(23), 53-65.

Kogut-Jaworska M. (2008), Instrumenty interwencjonizmu lokalnego w stymulowaniu rozwoju gospodarczego, CeDeWu, Warszawa.

Kożuch A. (2011), Rola samorządu terytorialnego we wspieraniu rozwoju lokalnego, [w:] Kożuch A., Noworól A. (red.), Instrumenty zarządzania rozwojem w przedsiębiorczych gminach, Kraków, Instytut Spraw Publicznych.

Kraśnicka T. (2002), Koncepcja rozwoju przedsiębiorczości ekonomicznej i pozaekonomicz$n e j$, Wydawnictwo AE w Katowicach, Katowice.

Makieła Z. (2008), Przedsiębiorczość regionalna, Difin, Warszawa.

Matejun M. (2005), Ocena systemu wspomagania matych i średnich przedsiębiorstw przez przedstawicieli instytucji działajacych $w$ otoczeniu biznesu, Zeszyty Naukowe. „Organizacja i Zarządzanie", 41(958), 49-60.

Matejun M. (2012), Regionalne instrumenty wspierania rozwoju małych i średnich przedsiębiorstw". [w]: Adamik A. (red.), Wspótpraca matych i średnich przedsiębiorstw w regionie. Budowanie konkurencyjności firm i regionu, Warszawa, Difin.

Płoszaj A. (2015), Instytucje otoczenia biznesu w Obszarze Metropolitarnym Gdańsk - Gdynia - Sopot. Raport opracowany na zlecenie OMG-G-S, Warszawa.

Polski J. (2013), Efekty zewnętrzne, jako czynniki aglo i deglomeracyjne, „Prace Naukowe Uniwersytetu Ekonomicznego we Wrocławiu”, 284, 142-149.

Russel P., Grycuk A. (2014), Zaangażowanie jednostek samorzadu terytorialnego $w$ Polsce w tworzenie instytucji wspierajacych przedsiębiorczość, „Studia BAS”, 1(37), 65-83.

Saar A. (2011), Jak samorządy lokalne moga wpływać na rozwój lokalnej przedsiębiorczości?. CeDeWu, Warszawa.

Skica T. (2009), Samorządy a rozwój przedsiębiorczości. Instrumenty wspierania przedsiębiorczości przez samorzad terytorialny na przykładzie gmin województwa podkarpackiego, Wyższa Szkoła Informatyki i Zarządzania w Rzeszowie, Rzeszów.

Skica T., Inglot-Brzęk E. (2017), Zróżnicowanie efektów stosowania instrumentów wsparcia przedsiębiorczości przez samorzad terytorialny z uwagi na kryterium kategorii rodzajowej gminy, ,Samorząd Terytorialny”, 6(318), 24-54.

Skica T., Inglot - Brzęk E. (2017), Kapitat społeczny, jako czynnik determinujacy skuteczność instrumentów wspierania przedsiębiorczości, „Samorząd Terytorialny”, 7-8(319-320), $57-82$.

Skica T., Rodzinka J., Harasym R. (2016). The Size of Local Administration and the Level of Entrepreneurship, Abstract opublikowany w materiałach pokonferencyjnych (RSA Conference Book), "Building Bridges: Cities and Regions in a Transnational World" RSA Annual Conference 2016, Graz, Austria, April 2016, Regional Studies Association, 164-165.

Skica T., Rodzinka J., Harasym R. (2017), Impact of Financial Policies of Local Authorities on Entrepreneurship: Comprehensiveness of Policy Matters, [w]: Jajuga K., Orlowski 
L., Staehr K. (eds), Contemporary Trends and Challenges in Finance, Wrocław, Springer Proceedings in Business and Economics, 257-269, DOI: http://dx.doi.org/10.1007/978-3-319-54885-2_24,

http://link.springer.com/book/10.1007/978-3-319-54885-2?page=2.

Skica T., Mickiewicz T., Rodzinka J. (2016), Lokalna polityka wsparcia przedsiębiorczości: Klasteryzacja, promocja, doradztwo i kapital społeczny, Wydawnictwo C.H. Beck, Warszawa.

Słomińska B. (2007), Gmina w procesach stymulowania przedsiębiorczości, „Samorząd Terytorialny", 3, 19-33.

Szepelska A. (2015), Działalność instytucji otoczenia biznesu w kontekście rozwijania przedsiębiorczości kobiet zamieszkatych obszary wiejskie województwa podlaskiego, „Przedsiębiorczość i zarządzanie. Firmy rodzinne - doświadczenie i perspektywy zarządzania”, 16(7), 367-378.

Walenia A. (2014), Rola instytucji w procesie wspierania lokalnej przedsiębiorczości (na przyktadzie wybranych gmin Podkarpacia), „Gospodarka i Finanse”, 4, 61-73.

Wychowanek J. (2014), Rola samorządu terytorialnego $w$ rozwoju sektora matych i średnich przedsiębiorstw na przykładzie Dolnego Ślaska, [w]: Laskowski P. (red.), „Prace Naukowe Wałbrzyskiej Szkoły Zarządzania i Przedsiębiorczości”, 28, 151-163.

\section{FACTORS DETERMINING THE LEVEL OF ECONOMIC ACTIVITY ON THE EXAMPLE OF MUNICIPALITIES WITH THE HIGHEST LEVEL OF ENTREPRENEURSHIP}

A b s tra ct. This paper attempts to build a profile of Polish municipalities, taking into account the factors which determine a higher level of entrepreneurship (in relation to other municipalities). To realize this goal, the authors took into account entrepreneurship support instruments used by the municipalities, as well as solutions used by business environment institutions. Based on a spatial analysis (global and local I Morana statistics), the authors presented the geographic distribution of clusters of municipalities with a similar level of entrepreneurship. The conducted research was supplemented with an analysis of economic activity determinants in municipalities with the highest level of entrepreneurship. Research showed that entrepreneurship is dependant not only from instruments belonging to local government units. Higher level of entrepreneurship is strongly connected with other factors. One of them is institutional support provided by local non governmental institutions. The next one is connected with localization and agglomeration benefits. The last one is a sum of all of these factors mentioned before. It means that focusing only on the instruments of entrepreneurship support by LGUs, is not enough to effectively support entrepreneurs. At least as much important as instruments, are other factors. Among them especially important is localization.

K e y w or d s: economic activity, entrepreneurship, municipalities with the highest level of entrepreneurship, local government instruments for entrepreneurship support, business environment institutions (BEI), spatial autocorrelation. 


\section{ANEKS}

Tabela 1. Statystyka globalna I Morana

\begin{tabular}{cc}
\hline Analizowane zmienne & Wskaźnik przedsiębiorczości \\
Poziom istotności & 0.05 \\
Macierz wag przestrzennych & 2480 \\
Liczba obiektów & Queen - bezpośredniego sąsiedztwa \\
\hline Moran's I & $\mathbf{0 , 4 6 2 7 2 8}$ \\
Oczekiwane I & $-0,000403$ \\
\hline Przy założeniu normalności & \\
Wariancja I & 0,000156 \\
Statystyka Z & 36,896513 \\
Wartość $p$ & $<0.000001$ \\
\hline Wrzy założeniu normalności & \\
Wariancja I & 0,000156 \\
Statystyka Z & 37,082657 \\
Wartość $p$ & $<0.000001$ \\
\hline
\end{tabular}

Źródło: Opracowanie własne przy wykorzystaniu oprogramowania PQstat.

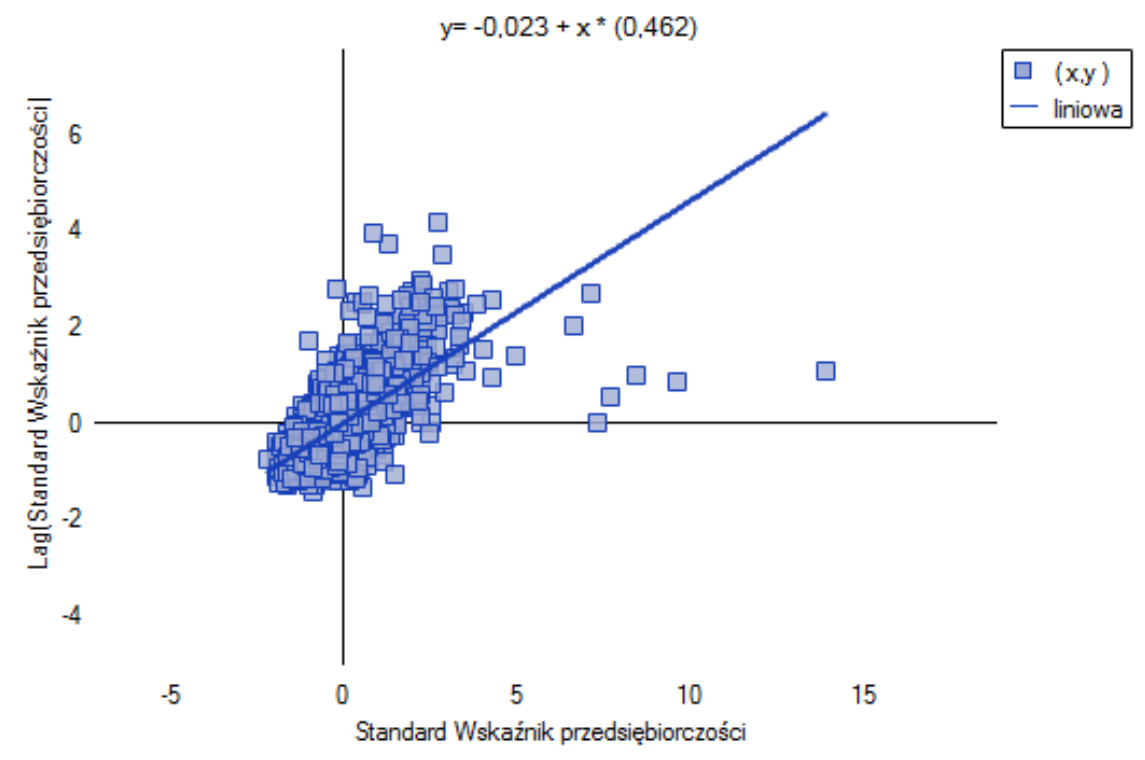

Wykres 1. Wykres rozrzutu I Morana

Źródło: Opracowanie własne przy wykorzystaniu oprogramowania PQstat.

AUNC, EKONOMIA 48 nr 1 (2017) 19-37 
Tabela 2. Statystyka lokalna I Morana

\begin{tabular}{ccc}
\hline Analizowane zmienne & Wskaźnik przedsiębiorczości & Wskaźnik przedsiębiorczości \\
Poziom istotności & 0.05 & 0.05 \\
Poprawiony poziom istotności & 0,008914 & - \\
(Bonferroni) & & - \\
Średnia liczba sassiadów & 5,609186 & Qú \\
Macierz wag przestrzennych & Queen - bezpośredniego sąsiedz- & Queen - bezpośredniego \\
& twa & sasiedztwa \\
Liczba obiektów & 2480 & 2480 \\
Wygładzanie zmiennej & - & locally wieghted averege \\
\hline Średnia li & 0,462168 & 0,741178 \\
Odchylenie standardowe li & 1,154762 & 1,657574 \\
\hline Liczność (Wysoka-Wysoka 1) & 155 & 288 \\
Liczność (Niska-Niska 3) & 80 & 287 \\
Liczność (Niska-Wysoka 2) & 1 & 0 \\
Liczność (Wysoka-Niska 4) & 0 & 0 \\
\hline
\end{tabular}

Źródło: Opracowanie własne przy wykorzystaniu oprogramowania PQstat.

Tabela 3. Statystyka lokalna $G_{i} \mid G_{i}{ }^{*}$ Getisa i Orda

\begin{tabular}{ccc}
\hline Analizowane zmienne & Wskaźnik przedsiębiorczości & Wskaźnik przedsiębiorczości \\
Poziom istotności & 0.05 & 0.05 \\
Macierz wag przestrzennych & Queen - bezpośredniego sąsiedz- & $\begin{array}{c}\text { Queen - bezpośredniego } \\
\text { sąsiedztwa }\end{array}$ \\
Liczba obiektów & 2480 & 2480 \\
Wartość własnego potencjału & - & 1 \\
\hline Średnia Gi| Gi* & 0,000399 & 0,000802 \\
Odchylenie standardowe Gi | Gi ${ }^{*}$ & 0,000112 & 0,000246 \\
\hline Liczność (Niska-Niska 1) & 216 & 90 \\
Liczność (Wysoka-Wysoka 2) & 229 & 178 \\
\hline
\end{tabular}

Źródło: Opracowanie własne przy wykorzystaniu oprogramowania PQstat. 